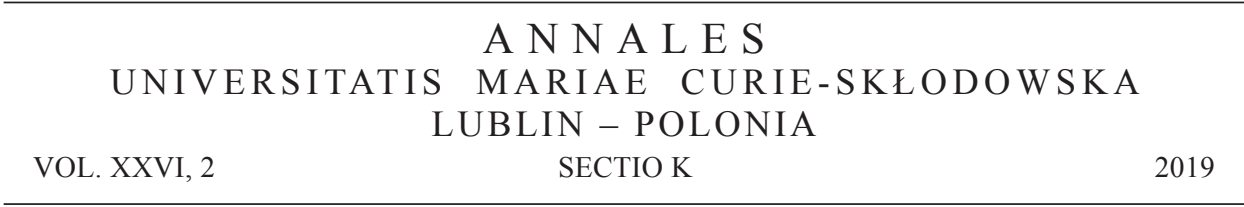

University of Tirana, Faculty of Social Science, Department of Political Science

\author{
GILDA HOXHA
}

ORCID ID: https://orcid.org/0000-0002-2211-7846

\title{
Social Movements Versus Frozen Democracy: The Albanian Perspective
}

\begin{abstract}
The main goal of the article is to identify the role of social and political movements and non-political forms of participating within a democratic system. Albania as a young democracy had been under organizational fragmentation. Albania has a stable political party system, but its society faces a chaotic development towards the democratization process. In this paper the main aim is to explain the role of social cleavages and social movements in a young democracy like Albania. The relationship between social movements and the political party system will be viewed from two perspectives: a) the relative openness or closure of the institutionalized political system; and b) how non-conventional forms of participation, such as a protest, can be part of policy-making. The paper is structured into two main parts, the first one deals with the theoretical approaches towards social movements and social cleavages and the second one relates to the Albanian perspective and its socio-political background.
\end{abstract}

Key words: social movements, Albania, democracy

\section{INTRODUCTION}

As Jakub Zielinski [2002: 184-211] argues, Eastern Europe's new democracies frequently undergo a period of organizational framework. If stable political parties are going to emerge sooner or later, than the chaotic competition between proto-parties that lack organizational stability and ideological cohesion. Thus, those new and young democracies tend to politicize social conflicts and emerging to new political parties. The translation of preexisting social cleavages into political conflicts reduces the number of political parties and translating the new social cleavages into political ones emerges once the political party system is frozen. 
Applying this rule from an Albanian perspective we could assume that the emergency for social movements is a necessity for the democratization process. Social movements could build and develop networks across society identifying social problems and defending against social injustices. What is unique for social movements is that "basic changes in social structure and in political structure occur together in a mutually reinforcing fashion and these changes occur through intense socio-political conflicts in which society plays a key role" [Mcmahon 2001: 145].

The objective of this paper is to examine the way in which the concept of mobilization is involved in the "transition" (democratization process) and what influence it has on building of democratic governance. The research was based on: case study reports prepared by non-governmental organizations (NGOs), information from reports, books devoted to the implementation of non-conventional forms of participation and mechanisms guaranteeing rights for these new forms of participation. The author aimed at highlighting the challenges and importance of the new forms of participation, once the political party system is frozen. The analysis was based on qualitative and quantitative research methods. It could be concluded that the Albanian political party system faces difficulties to represent the social cleavages due to political reasons, whereas mobilization of social movements helps the democratization process.

\section{THEORETICAL APPROACHES}

In this part of the paper we will try to understand the theoretical approaches and concepts related to social cleavages, social movements related to representation/ democracy. In many cases, mobilization from below (bottom-up initiatives) tends to be transformed in political parties. In countries and societies, which undergo the process of transition, social cleavages may have their roots in the past, or there may appear new ones and the society may face full or partial cleavages. In those cases, especially, when the political system is not yet consolidated, political parties are the major actor to represent the social cleavages. On the other hand, political parties are usually not able to represent the social cleavages in decision making. In such a case, social movements must replace them from the representative perspective.

Thus, by social cleavages, Seymour Lipset and Stein Rokkan emphasize that "cleavages do not translate themselves into party oppositions as a matter and crucial point in the discussion of the translation of the cleavage structures into party systems: the costs and the pay-offs of mergers, alliances, and coalitions" [Lipset, Rokkan 1967: 112]. According to Zielinski [2002], social cleavages (based on the Lipset and Rockan scheme) are identified as a) the national revolution which generated two conflicts: 1) the conflict between the central nation-building culture and the increasing resistance of the ethnically, linguistically or religiously diverse subject populations in the provinces and the peripheries; 2) the conflict between the cen- 
tralizing, standardizing and mobilizing nation-state and the historically established corporate privileges of the Church; b) the industrial revolution which, in turn, led to two additional conflicts: 1) the conflict between the landed interests and the rising class of industrial entrepreneurs; 2) the conflict between the owners and employers on the one side and the tenants, laborers and workers on the other. Thus, cleavages refer to conflict groups based on perceptions of associations in oppositions to others such groupings among large segments of population [Zuckerman 1975: 231-248].

Stefano Bartolini and Peter Mair [1990: 65-78] have reframed the concept of social cleavages, defining "«values and beliefs» as critical because of their contribution to a «sense of identity and role» and a group's «self-awareness»" [Berglund, Ekman, Deegan-Krause, Knutsen 2013: 36]. Thus, researchers agree that the notion of self-awareness includes more extensive surveys or research methods such as: demographic characteristics substituting for social closure; block substitutes for party; clientelist networks substitute for sociostructurally ties; values substitute for sociostructurally ties, etc. [Berglund et al. 2013: 40].

It can be noticed that Albania, after the fall of communism, seems to have all the possibilities for the development of cleavages, however, communism erased their socioeconomic basis. In the 1990s, after the regime changed, potential cleavages were based on the historical North-South division, the presence of anti-communist (parties), previous land owners, or political prisoners. Thus, almost all these potential cleavages were integrated within new political parties, mainly the Democratic Party. In my doctoral dissertation, I presented the failure of these political parties in terms of representing particular social groups in a parliamentary democratic system. The lack of social mobilization as for having influence on the decision-making process (by using non-conventional forms of participation) resulted in a slow democratization process. In addition, civil engagement in Albania varies due to many factors such as political culture, social and historical background, economic conditions and/ or democratization process.

Thus, most of social movements or civil engagement scholars relate them with social cleavages. In contemporary world many manifestations of social dissatisfaction are observable, related to the deficiencies in the traditional model of representative democracy [Marczewska-Rytko, Aksiuto, Maj, Pomarański 2018: 8]. According to Marc Hooghe [2005], "social movements can be conceptualized as sustained and enduring challenges to political decision makers in order to achieve some form of social change". It can be seen in different forms, such as civil rights movements, feminist movements, green movements, etc. Marco Giugni, Doug McAdam and Charles Tilly [1999] list some forms of protests, e.g.: "bus boycotts, sit-ins, freedom rides, marches, demonstrations and many other protests and acts of civil disobedience, thousands of people attempted to reinstate a sense of justice in the country" [Giugni et al. 1999: 65]. According to Roger Karapin,“(...) a social movement is one or more protest groups that engage in sustained collective action against some common opponents and with some common goals. The protest groups in a movement 
may often act independently of one another and may mobilize different or overlapping constituencies" [Karapin 2007: 20].

Pippa Norris's opinion on social movements refers to:

“(...) war, social policies, women's rights, civil rights, the natural environment, nuclear energy, ethnic rights, international economic policies, immigration etc. The nature of the protests and their outcomes were varied and complex. Protest rank represent new forms of political participation, raised new issues, enlivened public debates, and influenced policy reforms. Protesters also used violence, made anti-system demands, and provoked authorities to escalate their repressive responses" [Norris 2005: 21].

To differentiate social movements from other social organizations or even political parties we may conclude that movements are heterogeneous, by moments they are spontaneous, they are not hierarchical organizations and most importantly social movements are not mobilized to get the power and/or to govern. Thus, beside other forms of civil engagements, social movements and unconventional forms of participation are important to democracy, and especially to countries in a democratization process such as Albania, due to:

a) conventional political participation associated with the functioning of representative democracy, mainly with participation in election and involvement in the activities of political organizations; b) unconventional political participation comprising all forms of public involvement that have an obvious impact on public decisions and which are not directly related to the elections and operation of political parties; c) strictly social forms of participation, usually more private as well as public but non-political, which are implemented on a decidedly smaller scale, d) forms of psychological engagement that do not translate directly into civic activity and include, inter alia, paying attention to political and public events, feeling of concern about specific public issues, as well as having definite political convictions or social competence [Marczewska-Rytko et al. 2018: 9-10].

\section{ALBANIAN SOCIO-POLITICAL BACKGROUND: HOPE! DEMOCRACY!}

Most of the Albanian scholars relate democracy and democratization process in the 1990 with the student movement. Although the students or other social groups, under the communist regime theoretically existed, they do not really represent any social cleavage based on the Lipset and Rokkan scheme. However, in emergency cases, social movements tend to be organized when tensions between state institutions and society are reflected. The success of social movements depends on the relative openness of the institutionalized political system. If the political system offers facilities for non-conventional forms of participation, social movements usually succeed. 
Moreover, social movements, regardless the political system, can succeed when they are response to tense relations between the society and state structures. The success of Albanian student movement from the early 1990s could be referred to as an example where bottom-up mobilization may be essential for the democratization process.

The protest was the result of dissatisfaction over living conditions at the University of Tirana, between late November 1990 and December 1991. To the party structures, the students' life conditions were not the only concern, but the lectures on the history of the Party of Labour of Albania (PPSH), where students and some professors started to criticize the regime and economic conditions of society at that time. The then authorities were aware of the fact that young, educated people constituted a potential problem [Fevziu 2012].

Complete isolation and extreme poverty had extinguished the hope of most Albanians and this ultimately became the driving force behind the social movement. Dismal living conditions forced Albanians to take actions that sparked events leading to the democratization of Albania. Difficult economic conditions, which were in direct contradiction to the so-called propaganda of a new economic mechanism, and the situation at the university, gave rise to the protest of students. As a result, the first opposition political party was established.

Therefore, a priority for Albania in the 1990s was to build the legacy based on the party system. The lack of experience and well-established tradition of democracy and no representation under the conventional forms, such as political parties seemed to be a failure from the first free elections. The first opposition political party, Democratic Party, included in its first political program several main goals which were not well articulated. These were, inter alia, changes to the Albanian Constitution, free elections, a parliamentary governance system, market economy, etc. [Krasniqi 2009:36]. The other side, the PPSH, ${ }^{1}$ was trying to adapt to the new conditions and new challenges. The PPSH's popularity was confirmed in the first democratic elections in 1991 when it won the elections [Redaksia 2017]. As for the reason for that phenomenon, one can mention communist regime and its long-term impact on political culture [Murati 2013: 653]. Post-communist period has been characterized by political conflict, a high level party fractionalization, weak internal party democracy, dysfunctional parliamentary life, electoral and parliamentary boycotts and continuously changing "rules of game" [Murati 2013: 651-688].

Additionally, in the 1990s, there appeared a difference as far as particular regions are concerned. In 1912, during the first independent governance, the struggle for power was between the North and South. The northern (Geg) tribes did not approve the establishment of a strong central government that would threaten their traditional freedom [Panos 1997: 286]. In 1944, during the communist regime, this regional division was a taboo subject since no division officially existed, but the social-political

The PPSH adopted the political agenda towards the centre-left and changed the name to Socialist Party of Albania. 
attention focused on the South (Toskë) was visible by the politburo members. The fall of communism was seen by the North as a rebirth, new opportunities and new perspectives as the first opposition leader Sali Berisha was originally from the North. Until general elections in 2013, Berisha's hometown and the most important cities in the North voted for the Democratic Party (DP).

This regional division could have been transformed into social cleavage in order to increase the civil engagement, but political elite transformed it into political battle between the Democratic Party and the Socialist Party (SP). In 1997, Albania experienced another crisis sparked by pyramid scheme failures, lack of banking system, and harsh liberal economic reforms. Frustrated and disappointed Albanian citizens took the protests to the street. First riots started in the city of Vlorë in the southern of region of Albania (the South was considered as SP supporters) and spread all over the country. Clearly, the government was not able to prevent the events in 1997 since the schemes were not criticized immediately [Fevziu 2012: 106]. About 20,000 people were killed in 1997, however, none of the political elite found itself responsible. The excuse was the lack of experience in liberal democracy and market economy.

In 1998, owing to the international presence in Albania, new elections were held and the SP won the elections. In its campaign the party promised more controlled economic reforms and building a banking system in Albania. From 1998 to 2005, the political discourse was taking place between communists and anticommunists and mostly concerned corruption and anticorruption. Albanian citizens were not yet able to use the unconventional political forms of participation and were represented by political parties. This can mostly be explained by the experience from the past, migration and the lack of proper education in general, but especially lack of knowledge related to politics. Also, it should be mentioned that, based on data from the Albanian National Institute of Statistic [INSTAT 1998] the incomes for Albanian families were low and there were no middle or working class.

Due to political culture from the past both groups (previous land owners and expolitical prisoners) chose to be represented by traditional forms of political participation. As for the land owners, the DP promised (and it was a priority for the first four years of their governance) to solve the issue by a special law approved in 1993 - Law No. 7501 - establishing the land leasing [Fuga 2000: 71]. It could be said that even today, status of the land is considered an unsolved issue. Political prisoners, on the other hand, were organized in different associations and collaborated with political elite to resolve their issues such as monetary compensations.

Furthermore, the lack of mobilization and social movements in Albania in the first decade of democracy is also a result (alongside political culture) of transformation theories and practices. Thus, when describing social and political changes in Eastern Europe, the authors claim that these countries have undertaken important political and economic reforms, aimed at introducing "diversity" and consolidating democracy. The process of multiple transformation was presented by Claus Offe [1996: 65]. According to Adam Przeworski [1995: 35], a successful democratization model would 
include answers to the following question: 1) What kind of economic systems are most likely to generate growth with a humane distribution of welfare?,2) What kind of democratic institutions are most likely to last?, 3) What are the political conditions for the successful functioning of economic systems, for growth with security for all?, 4) What are the economic conditions for democracy to be consolidated? From Przeworski's point of view, the source of hope that Eastern Europe will escape the politics, the economics and the culture of poor capitalism, and that it will soon join the West is geography owing to which East European countries will follow the path to democracy and prosperity [Jović 2010: 44-68].

\section{YOUNG ALBANIAN GENERATION: A DIFFERENT PERSPECTIVE}

Zielinski [2002] argues that if social conflicts can be non-politicized, then a society with a historical cleavages on issues $x$ and $y$ can evolve in four different ways: a) both conflicts are translated, b) only conflicts on issue $x$ is translated, c) only conflicts on issue $y$ is translated and d) none of the conflicts are translated. Albanian society seems to be worth paying attention to due to fulfilling these conditions in order to instigate non-political conflict the outcome of which was left to the interplay of political forces. As Lipset and Rokkan mention, all the common social cleavages and their reasons, like ethnicity, religion or social inequalities vanished or were reshaped based on political system interest.

In recent years, in Albania, the involvement of the young generation is aimed at limiting all the conditions necessary to create social divisions and movements. The young generation is different from the 90 s generation, e.g. in terms of education. In the 18-35 age group, $24.1 \%$ declare they have higher education. Access to technology and information through social media, as well as the possibility to move freely in Europe (in 2011, Albania was part of the Schengen Area) are just some of the reasons why civic engagement was successful. What is more, it is only after 2000 that the concept of rehabilitation of protests [Mjaft 2019] through civic involvement is visible in Albanian society, due to the involvement of the young generation in public affairs.

The most famous movement in 2000 was "Mjaft" (Eng. "enough"), in which participants were students who returned after studying in West European countries. The strong symbolism used in this protest changed the way in which it was perceived. It became a tool used not only by political parties and elites. Exceptional case, are student protest on neo-liberal reform in higher education, starting since to 2015. The biggest protest was in December 2018, ${ }^{2}$ known as the "Second December". Debate over the higher education reform in Albania started in 2011, where the

In case of all the events described in this paper (student movements and 2013 protest), the author of the paper witnessed those events and was granted permission to use participants' statements. 
main goal for this reform was credibility and the adoption of the Bologna system in Albanian universities.

For the last five years, protests and discussions over the new reform on higher education took place with different groups: students and professor supporter, opinion makers, journalist, etc. - Lëvizjapër Universitetin (Movement for the University) [Hoxha 2018: 25-34]; professors and other academicians within the University of Tirana - Forumi për Liri Akademike dhe Autonominë Universitare (Forum for Academic Freedom and University Autonomy). Both of these groups share common points and goals especially in terms of the University's autonomy, financial transparency and academic research. On December 6, 2018, due a government decision on university fees for the second semester of the 2018/2019 academic year, starting with the Department of Finance of the Faculty of Architecture and Urban Planning, students from this faculty began spontaneous protesting in front of the Ministry of Education, Sport and Youth. The next day those students were supported by their colleagues from other faculties. Two days later, more than 15,000 students from all over Albania were protesting in a very peaceful way, drawing public opinion's attention and sharing concern about higher education.

The student street protests lasted for more than 3 weeks and by January they were organized within the Faculty buildings. This way of boycotting (by February) was a common decision of students, professors, and deans of the Faculty and was a step toward autonomy. Although Prime Minister Edi Rama began visiting the universities of Albania with the intention of starting a dialogue, at most of such meetings students either boycotted the meeting (according to students they were not informed about the presence of the Prime Minister) or insisted on fulfilling their demands. In December, on the initiative of the prime minister, the government approved the "Pact for the University". This pact provides fees reduced by half and/or completely for students with high average, students with special skills (Bachelor's studies). In the case of Master's studies, fees will remain almost the same or their amount will be determined by individual faculties. The student basket will be active in 2019 and living conditions in the dormitory will improve. However, from the students' point of view, these changes are introduced too late and are not entirely unfair. Albania's historical background proves that democratization process, translates the existing social cleavages (and new ones) into political conflicts, thus, the evolution of new political parties is present. Since 1992, in Albania, there have been more than 63 political parties, however, the country is still struggling to build a consolidated democracy.

\section{CONCLUSIONS}

Albania is one example of a country where a lack of transparency in relation to government institutions prevents social movements from taking their necessary role in the democratization process, namely decision-makers must take responsibil- 
ity for them. To reach this conclusion, it was necessary to analyze the progress that took place in Albania in comparison with other communist countries, where civic engagement activity throughout Europe was not able to successfully achieve its goals.

It may be said that the lack of mobilization in young democracies like Albania has also some other important reasons from the past. For example, Albanians had a different development in terms of social divisions caused by national and industrial revolutions. Moreover, the totalitarian regime had its impact on social cleavage and was always under the system control.

In 1992, when the system changed, possibilities to have the social cleavages which would help in terms of civil engagement also may be considered a failure. Shortly speaking, right after bringing democracy, social groups, e.g. ex land owners, were mostly organized within political parties. Most of the potential social groups could initiate cleavages but the conflicts were translated as political one and helped with establishing new political system and political parties were able to survive in uneasy period. New social cleavages in Albania, reshaped during the democratization process, seem to be politicized and turn democracy into a frozen one. It may be said that only after 2000, the Albanian society was able to rehabilitate the protest concept and civil engagement, due to many factors such as education, technology and opportunities to travel abroad and the young generation's role (students) was of great significance as far as this aspect is concerned.

\section{BIBLIOGRAPHY}

Bartolini, S., Mair, P. 1990. Identity, Competition and Electoral Availability. The Stabilization of European Electorates 1885-1985, Cambridge University Press, Cambridge.

Berglund, S., Ekman, J., Deegan-Krause, K., Knutsen, T. 2013. The Handbook of Political Change in Eastern Europe, Edward Elgar, Cheltenham.

Fevziu, B. 2012. 100 Vite shtet, nje ekskursion ne politiken e shtetit shqiptar nga 1912-2012, UET Press, Tirana. Fuga, A. 2000. Shoqeria Periferike, Ora, Tirane.

Giugni, M., McAdam, D., Tilly, C. 1999. How Social Movements Matter: Past Research, Present Problems, Future Developments, University of Minnesota Press, Minneapolis.

Hooghe, M. 2005. Ethnic Organisations and Social Movement Theory: The Political Opportunity Structure for Ethnic Mobilisation in Flanders, "Journal of Ethnic and Migration Studies", vol. 31(5), pp. 975-990, DOI: https://doi.org/10.1080/13691830500177925.

Hoxha, G. 2018. Albanian November, Students Calling, "Baltic Worlds", vol. XI(I), pp. 25-35.

INSTAT. 1998, http://www.instat.gov.al/en/themes (access: 22.12.2018).

Jović, D. 2010. Problems of Early Post-Communist Transition Theory: From Transition from to Transition to, "Politička Misao", vol. 47(5), pp. 44-68.

Karapin, R. 2007. Protest politics in Germany: movements on the Left, Pennsylvania State University Press, Pennsylvania.

Krasniqi, A. 2009. Patite Politike ne Shqiperi (1991-2008): historia, proceset zgjedhore, kandidatet, fushata elektorale, Dhoma Britanika e Tregetise dhe Industrise ne Shqiperi (ABCCI), Tirana.

Lipset, S.M., Rokkan, S. 1967. Party Systems and Voter Alignments: Cross-National Perspective, Free Press, New York. 
Marczewska-Rytko, M., Aksiuto, K., Maj, D., Pomarański, M. 2018. Civil Participation in the Visegrad Group Countries after 1998, Maria Curie-Skłodowska University Press, Lublin.

Mcmahon, P. 2001. Building Civil Societies in East Central Europe: The Effect of American Nongovernmental Groups, Frank Cass and Company Limited, London.

Mjaft. 2019, https://www.mjaft.org/en/who-we-are (access: 16.06.2019).

Murati, A. 2013. Albania, [in:] The Handbook of Political Change in Eastern Europe, S. Berglund, J. Ekman, K. Deegan-Krause, T. Knutsen (eds.), Edward Elgar, Cheltenham-Northampton, pp. 651-688.

Norris, P. 2005. Political Activism: New Challenges, New Opportunities, Oxford University Press, Oxford.

Offe, C. 1996. Varieties of Transition: The East European and East German Experience, Polity Press, London.

Panos, N. 1997. The Process of Democratization in Albania, [in:] Politics, Power and the Struggle for Democracy in South-East Europe, K. Dawisha, B. Parrott (eds.), Cambridge University Press, Cambridge.

Przeworski, A. 1995. Sustainable Democracy, Cambridge University Press, Cambridge.

Redaksia. 2017. Zgjedhjet pas viteve '90-të/ Këto zgjedhjet e 9-ta, ja kronologjia dhe fituesit, "Panorama", 27.06, pp. 3-4.

Shqip, G. 2018. Forumi për Liri Akademike-Ramës: Refuzojmë gjuhën shantazhuese, "Zgjidhje ose grevë Gazeta Shqip", 14.02, pp. 3-4.

Zielinski, J. 2002. Translating Social, Cleavages into Party System. The Significance of New Democracies, "World Politics", vol. 54(2), pp. 184-211.

Zuckerman, A. 1975. Political Cleavage: A Conceptual and Theoretical Analysis, "British Journal of Political Science", vol. 5(2), pp. 231-248, DOI: https://doi.org/10.1017/S0007123400008140.

\section{BIOGRAPHY}

Gilda Hoxha, graduated in Political Science, University of Tirana in 2010. She obtained her MsC degree in Political Theory in 2012 (Faculty of Social Science, University of Tirana) and in 2013 a MsC degree in Political Science and International Relations (Epoka University). Lately, she obtained a doctoral degree in Political Science Department, Faculty of Social Sciences. University of Tirana. Member of the Swedish Institute Alumni Network; Program for $\mathrm{PhD}$ and Postdoctoral research for the Western Balkans, Södertörn University, Stockholm. Additionally, she has been a part-time lecturer since 2012 in the Department of Political Science, Faculty of Social Science and a lecturer at the Mediterranean University of Albania. E-mail: gildahoxha@gmail.com; gildahoxha@umsh.edu.al 